Fr. Cezary Smuniewski*

Akademia Sztuki Wojennej, Warszawa

\title{
“ET STUPEBANT SUPER DOCTRINA EJUS” (MK 1:22). ON THE ROLE OF WONDERMENT IN THE THEOLOGICAL METHOD
}

The study is a contribution to research on the theological method and shows the motif of wonderment in the teaching and poetry of John Paul II as an experience inviting man to get to know God and His works ever more deeply. The human experience of being amazed with God has been presented as a theological event a grace of the ability to stand in awe of God, to get closer to Him and to speak about Him. The author of the article comes to the conclusion that the mission of a theologian is inseparably connected with cultivating the ability to be amazed with God and His works. The experience of wonderment is one of the elements leading to communion with Christ the Theologian, who reveals the Father.

\section{INTRODUCTION}

The aim of this study is to show the motif of wonderment and at the same time to try to recognize in this motif the content that can be useful in research on the theological method and thus indirectly on the mission of the theologian. The choice of sources which became the basis for the analysis was determined by the main idea - striving to show wonderment as one of the elements influencing the theological thinking and the experience of faith. The quoted documents and studies were selected with regard to their relation to the theological and semantic problem space, defined by the main goal. Priority was given to John Paul II's

* Rev. Fr. Cezary Smuniewski - Roman Catholic presbiter, PhD in Theology, PhD in Security Studies, Professor of the War Studies University in Warsaw; ORCID: https:// orcid.org/0000-0002-8973-3539. 
texts as appealing to the contemporary reader and characterised by a relatively high frequency of the presence of the lexeme "wonderment" in his teaching and poetic works. ${ }^{1}$

\section{THE PROBLEM}

Direct inspiration for the research on the theological method ${ }^{2}$ and the astonishment was the text from St Mark's Gospel: "Et ingrediuntur Capharnaum. Et statim sabbatis ingressus synagogam docebat. Et stupebant super doctrina eius: erat enim docens eos quasi potestatem habens et non sicut scribae" (Mk 1:21-22) ${ }^{3}$. We should not miss the reaction of those who listened to the teacher on the Sabbath in Capernaum described in this sentence. They wondered at hearing Jesus' teachings. We also read about wonderment in the Acts, when it is said about the reaction of the people to the healing of the man lame from birth. The author wrote the following words in this Book: "Et vidit omnis populus eum ambulantem et laudantem Deum; cognoscebant autem illum quoniam ipse erat, qui ad eleemosynam sedebat ad Speciosam portam templi, et impleti sunt stupore et exstasi in eo, quod contigerat illi"

1 I received the information from the Latin section of the Secretariat of the Holy See that the lexeme "stupor" and "admiratio" in the Latin version of John Paul II's texts are used synonymously. This also applies to the "wonderment" mentioned by John Paul II in the Roman Triptych a work that was composed in Polish. [Translator's note: "wonderment" and "amazement" will be used interchangeably in the English translation].

2 The following texts were important inspirations for reflection on the theological method: G. Strzelczyk, Własne doświadczenie wiary teologa jako integralny element metody teologicznej, in: Teologia na nowe tysiaclecie. Między barbarzyństwem a nadzieja, ed. J. Kempa, I. Bugdoł, Katowice 2005, p. 105-122; Il metodo teologico. Tradizione, innovazione, comunione in Cristo, ed. M. Sodi, Città del Vaticano 2008; M. Rusecki, Problematyka metody w teologii, in: Tożsamość teologii, ed. A. Anderwald, T. Dola, M. Rusecki, Opole 2010, p. 43-83; J. Królikowski, Nauka, madrość i powołanie. O naturze i misji teologii, Kraków 2016. In the book by Janusz Królikowski we read: "Today's theology experiences a fundamental deficit precisely in the reflection on issues concerning its nature and method, i.e. those which should also deal with defining its subject. This can be seen, for example, in the frequent failure to distinguish between the method and methodology, or in the disregard for this issue in the teaching of theology" (p. 27).

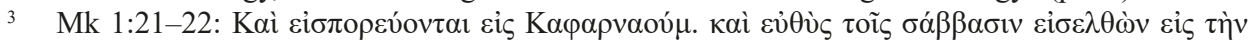

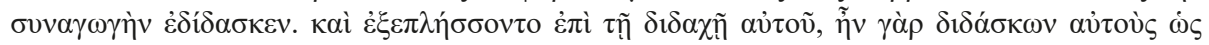

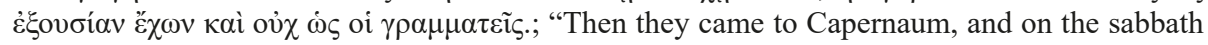
he entered the synagogue and taught. The people were astonished at his teaching, for he taught them as one having authority and not as the scribes". 
(Acts 3:9-10)4. In this sentence, "wonderment" is preceded by "elation," in which, if we refer to the Greek and Latin texts, we recognise something close to ecstasy (stupore et exstasi). The order of the two expressions of the experience of a people who have witnessed a miracle is not accidental. Amazement is the first step, introducing into this experience. It is precisely the motif of wonderment that is repeatedly attested to in various texts of John Paul II. ${ }^{5}$ This applies both to his texts containing pontifical teachings and to his literary work. In the fragments containing this motif, one can find content that seems to be significant for understanding theology and the theologian's vocation in the community of believers, in the Church. Referring to the thought of the contemporary Polish theologian Jerzy Szymik, one can say that it is also about crossing the threshold of wonderment. This step is not only a poetic and theological act, but probably also an existential one, deeply rooted in the imagination and language of John Paul II. ${ }^{6}$ This fact entitles us to pose questions about the role of amazement in the process of theological research. In its background one should hear the statement of the Second Vatican Council from the Pastoral Constitution on the Church in the Modern World. In this document we read: "[...] Ecclesia in mentem omnium revocat culturam ad integram personae humanae perfectionem, ad bonum communitatis et totius humanae societatis esse referendam. Quare oportet animum ita excolere, ut promoveatur facultas admirandi, intus legendi, contemplandi atque efformandi iudicium personale et excolendi sensum religiosum, moralem ac socialem". ${ }^{7}$ Even though this text talks directly about culture and the human person, it also seems to direct the reader towards the principles of theological thinking. After all, true theology is meant to serve faith the relationship between man and God, which involves arousing the spirit, so that the ability to admire would develop, followed by: learning the essence of things,

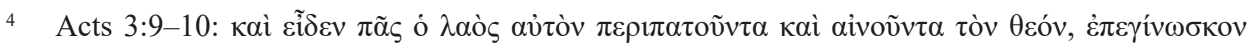

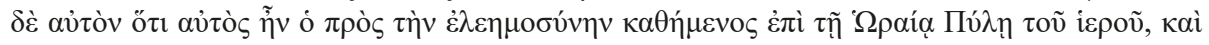

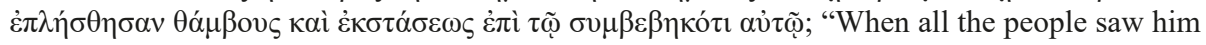
walking and praising God, they recognized him as the one who used to sit begging at the Beautiful Gate of the temple, and they were filled with amazement and astonishment at what had happened to him".

5 Cf. C. Smuniewski, Wspólnota łaski. Charytologiczno-trynitarna eklezjogeneza, "Myśl Teologiczna" 76 (2013), p. 10-18.

6 Cf. J. Szymik, Przekroczyć próg zdumienia. O “Tryptyku rzymskim” Jana Pawła II, in: Karol Wojtyła - poeta, ed. J. Głażewski, W. Sadowski, Warszawa 2006, p. 63.

$7 \quad 2^{\text {nd }}$ Vatican Council, Pastoral Constitution on the Church in the Modern World. Gaudium et spes, No. 59: "[...] the Church recalls to the mind of all that culture is to be subordinated to the integral perfection of the human person, to the good of the community and of the whole society. Therefore it is necessary to develop the human faculties in such a way that there results a growth of the faculty of admiration, of intuition, of contemplation, of making personal judgment, of developing a religious, moral and social sense". 
contemplating, forming personal judgment, perfecting the religious, moral and social sense. The sentence written by St Mark "Et stupebant super doctrina ejus" (Mk 1:22) and the statement of the Second Vatican Council "[...] ut promoveatur facultas admirandi $[\ldots]$ " recall the words of Aristotle written in Metaphysics: "It was thanks to wonder that the present people, as well as the first thinkers, began to philosophize; they were surprised at first by the unusual phenomena encountered every day, and then slowly faced more difficult issues, such as those related to the Moon, the Sun and the stars, and to the creation of the universe."

\section{SEMPER OPORTET HIC STUPOR...}

Let us move on to the texts of John Paul II. In his last encyclical, dedicated to the Eucharist, which in many respects contains author's personal reflections, the Pope discreetly introduces the theme of "wonderment." This may seem like a detail in the multitude of issues presented there and the complexity of the papal message. However, considering the whole of John Paul II's thought, the theme of "wonderment" from Ecclesia de Eucharistia undoubtedly has a significant message. In this text, the Pope speaks not only of a feeling of great and grateful amazement ${ }^{9}$ in the context of the gift of the Blessed Sacrament and its timelessness, but also of the Church's attitude towards God's gift. Let us quote from the Encyclical: "In the paschal event and the Eucharist which makes it present throughout the centuries, there is a truly enormous 'capacity' which embraces all of history as the recipient of the grace of the redemption. This amazement should always fill the Church assembled for the celebration of the Eucharist." 10 One of the goals that John Paul II set for himself when writing his encyclical was to awaken the "Eucharistic 'astonishment'."11

We read about "amazement" already in the first encyclical of the Polish Pope, in which, as is often emphasized in commentaries, the author included his programme for the next years of the pontificate. It should be noted that that it says about a "deep wonder" 12 of man at himself, which is the fruit of getting nearer

Aristotle, Metaphysics I, 2 (982 b).

9 Cf. John Paul II, Encyclical "Ecclesia de Eucharistia", No. 5. In the Latin text this expression is: Haec nos cogitatio ad affectus perducit magni gratique stuporis.

10 John Paul II, Encyclical "Ecclesia de Eucharistia", No. 5. In the Latin text: Semper oportet hic stupor Ecclesiam pervadat in eucharistica Celebratione congregatam.

11 Cf. John Paul II, Encyclical "Ecclesia de Eucharistia”, No. 6. In the Latin text: eucharisticum "stuporem".

12 Cf. John Paul II, Encyclical “Redemptor hominis”, No. 10. In the Latin text: verum etiam magna sui ipsius admiratione. 
Christ, together with the whole truth about himself. "In reality, the name for that deep amazement at man's worth and dignity is the Gospel, that is to say: the Good News. It is also called Christianity."13 This amazement determines the Church's mission in the world." 14 This amazement defines the calling of the Church in the world. "This amazement, which is also a conviction and a certitude - at its deepest root it is the certainty of faith, but in a hidden and mysterious way it vivifies every aspect of authentic humanismis closely connected with Christ. It also fixes Christ's place - so to speak, his particular right of citizenship - in the history of man and mankind." 15 It is not without its meaning for thinking about the theological method that together with "amazement" John Paul II speaks of "conviction" and "certainty of faith." For what is meant here is knowledge. This is easier to perceive in the next sentence, in which the Pope introduces the theme of contemplating the mystery of Christ and again emphasizes the certainty of faith. ${ }^{16}$

The "admiratio" lexem is confirmed in the text of the exhortation Pastores dabo vobis in the quotation made by John Paul II from one of the main works of St. Bonaventure - Itinerarium mentis in Deum ${ }^{17}$. The quote from the Seraphic Doctor is as follows: "Ne quis forte credat quod sibi sufficiat lectio sine unctione, speculatio sine devotione, investigatio sine admiratione, circumspectio sine exsultatione, industria sine pietate, scientia sine caritate, intellegentia sine humilitate, studium absque divina gratia, speculum absque sapientia divinitus inspirata"18. For the thinking about theological method it is not insignificant that this text is quoted when the topic of intellectual formation of the future priests is discussed, which is associated with two issues. This is about the understanding of theological

13 John Paul II, Encyclical "Redemptor hominis", No. 10. In the Latin text: Re quidem vera miratio maxima illa de pretio ac dignitate hominis nuncupatur Evangelium, id est Bonus Nuntius. Vocatur item Christianismus.

14 Cf. John Paul II, Encyclical "Redemptor hominis", No. 10. In the Latin text: Ex eadem ipsa admiratione proficiscitur Ecclesiae munus in hoc mundo.

15 John Paul II, Encyclical "Redemptor hominis", No. 10. In the Latin text: Haec porro miratio simulque persuasio et certitudo...

16 Cf. John Paul II, Encyclical "Redemptor hominis", No. 10. In the Latin text: Ecclesia, quae contemplari non cessat totam mysterii Christi summam, novit ex certa sua fide.

17 Here I am using: S. Bonaventurae, Opera omnia, vol. 1-10, Publisher Ad claras Aquas (Quaracchi): Ex typographia Colegii S. Bonaventurae 1882-1902, https://archive.org/details/doctorisseraphic11bona.

18 S. Bonaventurae, Itinerarium mentis in Deum, Prol. 4, in: Opera omnia, vol. 5, Publisher Ad Aquas Claras (Quaracchi): Ex typographia Colegii S. Bonaventurae 1891, p. 296. In the English edition of Pastores dabo vobis this text is as follows (No. 53): „Let no one think that it is enough for him to read if he lacks devotion, or to engage in speculation without spiritual Joy, or to be active if he has no piety, or to have knowledge without charity, or intelligence without humility, or study without God's grace, or to expect to know himself if he is lacking the infused wisdom of God". 
studies, the nature of theology, the aim of theology, the principles of working out and studying the sacred doctrine, but also about the understanding of a theologian, about whom the document says concisely: "The theologian is therefore, first and foremost, a believer, a person of faith. But the theologian is a believer who asks himself questions about his own faith (fides quaerens intellectum), with the aim of reaching a deeper understanding of the faith itself. The two aspects (of faith and mature reflection) are intimately connected, intertwined." 19 One of the greatest Polish theologians of the turn of the $20^{\text {th }}$ and $21^{\text {st }}$ century - Jacek Salij OP - commenting on this fragment of the exhortation, states: "A theologian should be the kind of a believer who is most obliged to reflect on faith. [[...] [Theologian - C.S.] is someone who deeply believes, loves Jesus Christ, united in his faith with the Church, reflecting on the truths of faith with religious pietism and treating his search as a service to God's people." ${ }^{20}$ Despite the fact that in the text quoted here the academic does not speak directly of the amazement or admiration that should accompany a theologian in his work, it is impossible not to have the impression that mere academic enthusiasm and the reliability of research are not enough to practise true theology. What makes it possible to be a theologian and guarantees the truthfulness of the science one practises is, as Jacek Salij wrote, "a real experience of God." However, it is about an experience that results in "holiness." 21 This is because being a theologian involves an apparent limitation. As Jacek Salij wrote: "There is only one Theologian in the full sense of the word - who not only knows God directly, but knows Him to the end, all His infinity." ${ }^{22}$ Obviously in this text he speaks of Jesus Christ, as we read in the Gospel: "No one has ever seen God; the only God, who is at the Father's side, he has made him known"23 (Jn 1:18; see Jn 6:46; Matt 11:27). We are talking about a limitation because, "there is only one Theologian," and all the others are theologians as long as they are in communion with the "only Theologian." This is only an apparent limitation, because in no other field of science do scholars have as wide access to the subject of their own research as do theologians in Jesus Christ, who reveals God. It is therefore difficult to speak of a real constraint. The Incarnate Son of God - the Theologian - is the Father's openness to being known by man; it is His invitation addressed to man to get to know the Father. Communion with Jesus Christ

\footnotetext{
John Paul II, Exhortation "Pastores dabo vobis", No. 53.

J. Salij, Jan Pawet II jako teolog, in: idem, Wiara i teologia ..., p. 196, 198.

${ }_{21}$ Cf. J. Salij, Czy możliwa jest teologia chrześcijańska poza Kościotem?, in: idem, Wiara i teologia ..., p. 132.

22 J. Salij, Teologia czasu próby, in: idem, Wiara i teologia..., p. 77.

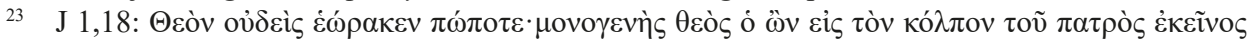
$\dot{\varepsilon} \xi \eta \gamma \eta ́ \sigma \alpha \tau$.
} 
becomes an experience of being a theologian in the Theologian. Just for clarity's sake, let us recall that both the knowledge of God and communion with the Son of God are possible only in love. Should this state of affairs, this apparent limitation, not be revealed in theologians in their attitude of thanksgiving to God? If so, then perhaps this thankfulness should be preceded by "unflagging amazement." Assuming that the grace of being a theologian, that is, the ability to commune with the "Theologian," is a gift that transcends the temporal, is an anticipation of the eternal knowledge of God in eternity, we can speak of such gratitude and the astonishment that precedes it, about which John Paul II wrote in his encyclical Evangelium vitae. In this text we read: "Eternal life is therefore the life of God himself and at the same time the life of the children of God. As they ponder this unexpected and inexpressible truth which comes to us from God in Christ, believers cannot fail to be filled with ever new wonder and unbounded gratitude." ${ }^{24}$

\section{...MAN CAN MARVEL!}

Thinking about the theological method in the context of the human ability to wonder leads inevitably to reflection about man. It is man who is equipped with this ability and, at the same time, is called upon to become a theologian in Theologian through communion with the Incarnate Son of God. It is therefore necessary to reflect on the man-theologian as someone who wonders. At this point the poetic work of John Paul II - The Roman Triptych - comes to our aid. It is, by all means, an exceptional testimony to the Pope-theologian's reflection on amazement and human capabilities. It is in The Roman Triptych, in its first part entitled The Stream, that he deals extensively with the subject of wonderment. The lexeme "wonderment" was used by the author as the first subheading opening the whole work. The second and third parts of the Wonderment are significant, and there we read:

What are you saying to me, mountain stream?

Where, in which place, do we meet?

Do you meet me who is also passingjust like you.

But is it like you?

24 John Paul II, Encyclical "Evangelium vitae", No. 38. In the Latin text: Qua de re, vita aeterna est ipsa Dei vita simulque vita filiorum Dei. Pius vir admiratione et immensa gratiarum actione non potest non repleri prae hac insperata et ineffabili veritate, quae a Deo ad nos profluit in Christo. 
(Allow me to pause here;

allow me to stop at a threshold,

the threshold of simple wonder).

The running stream cannot marvel,

and silently the woods slope down,

following the rhythm of the stream-

but man can marvel!

The threshold which the world crosses in him

is the threshold of wonderment.

(Once, this very wonder was called 'Adam') ${ }^{25}$

The synecdochal astonishment, as Ewa Szczęsna notes, ${ }^{26}$ is a representation of thinking, reflectivity, but also of spirituality, thanks to which it is possible to meet the "Eternal Word," i.e. to enter into dialogue with God. In this way it becomes possible to reach the mystery of passing and beginning. In The Roman Triptych, man is shown as a reflective being. For God speaks to him in the silence of the created world, hence the verses taking on the character of an oxymoron:

How remarkable is Your silence

in everything, in all that on every side

unveils the created world around us... ${ }^{27}$

The problem of silence introduced in the quoted work is directly related to man's wonderment. Quiet and silence are generally a significant element of communication, they do not replace speech, but have their own functions to fulfil in the discourse. Even a cursory look at the semantic field of "silence" in the poetry of Karol Wojtyła/ John Paul II, as Marta Falkowska writes, allows us to state that the basic context in which impressions of silence appear is the situation of entering into close contact with God. However, silence is not only an indispensable condition for meeting God and His action. "Silence begins - or perhaps only intensifies? - already after entering into prayerful contact with God, when amazement, admiration, and finally the awareness of the impossibility of expressing one's spiritual experience in language arises in man - hence man's becoming

25 John Paul II, The Roman Triptych, transl. J. Peterkiewicz, https://www.ewtn.com/catholicism/ library/roman-triptych-8369.

26 Cf. E. Szczęsna, Namyst, zdziwienie zapytywanie - o poetyce interpretacji na przykładzie ,, Tryptyku rzymskiego" Jana Pawta II, in: Karol Wojtyła - poeta..., p. 54-55.

27 John Paul II, The Roman Triptych... 
speechless." ${ }^{28}$ According to Alfred M. Wierzbicki, amazement can be regarded as "the most elementary form of contact with oneself, experiencing oneself from within and at the same time against the background of the whole world arousing admiration." 29 The high frequency of use of the lexeme "wonderment" is noticeable in the next part of the poem. We are dealing here with repetitions, which play an important role in Karol Wojtyła's poetry and are one of his favourite artistic devices. ${ }^{30}$

He was alone in his wonder, among creatures incapable of wonder-

for them it is enough to exist and go their way.

Man went his way with them,

filled with wonder!

But being amazed, he always emerged

from the tide that carried him,

as if saying to everything around him:

'Stop-in me is your harbour,'

'in me is the place of meeting

with the Primordial Word.'

'Stop, this passing has meaning...

has meaning... has meaning'. ${ }^{31}$

In John Paul II's thought, the uniqueness of man consists, among other things, in that he has the ability to wonder: "man can marvel!"; "He was alone in his wonder, among creatures incapable of wonder - for them it is enough to exist and go their way." Analysing the poem of the poet Pope, Jerzy Szymik writes about amazement as an arch-human feature, distinguishing man from creatures. He also notes that John Paul II defines the greatest concepts of the human and Christian universum by means of the category of wonderment. ${ }^{32}$ It is precisely the ability to be amazed that makes man different - "The running stream cannot marvel."

${ }_{28}$ M. Falkowska, Cisza i „,milczenie” w poezji Karola Wojtyly, in: Karol Wojtyła - poeta..., Warszawa 2006, p. 94.

29 A.M. Wierzbicki, Pomiędzy zdziwieniem a widzeniem, in: Wokót „Tryptyku rzymskiego” Jana Pawta II, ed. idem, Lublin 2003, p. 89.

30 Cf. T. Borucki, O wzniostości w poemacie medytacyjnym na przykładzie polskiej i rosyjskiej wersji „Tryptyku rzymskiego" Jana Pawła II, in: Między oryginałem a przekładem, vol. 16: Wzniostość i styl wyskoki w przektadzie, ed. J. Brzozowski, M. Filipowicz-Rudek, Kraków 2008, p. 16.

31 John Paul II, The Roman Triptych...

32 Cf. J. Szymik, Przekroczyć próg zdumienia..., p. 62. 
The ability to amaze in a sense defines man - "Once, this very wonder was called "Adam'." The author states that a barrier, a "threshold," is "crossed" in man. This is a fundamental event, because it is the "world" that passes through this border: "The threshold which the world crosses in him is the threshold of wonderment." This phrase brings to mind the book Crossing the Threshold of Hope - a long interview with Pope by Vittorio Messori. ${ }^{33}$ The Roman Triptych speaks of crossing the threshold of wonderment, and the interview speaks of crossing the threshold of hope, which is similar to the title of the book. This approach opens up a perspective for talking about the relationship between amazement and hope. And if this is the case, then one should ask: what kind of hope is it about? what does it concern? what future does it point to? Wonderment appears to be a feature that opens man up to cognition, enables him to be cognitive and allows them to enter into what lies ahead. "Man went his way with them, / filled with wonder! But being amazed, / he always emerged / from the tide that carried him."

Through man's mediation (which must be understood in relation to Christ's only mediation), the remaining created reality opens up to another dimension of its existence, the transformed existence, because it is redeemed in the incarnate Son of God who became man. Man therefore receives a new role in the whole created world. It is as if he speaks to everyone around him: "Stop-in me is your harbour,' 'in me is the place of meeting / with the Primordial Word." This is about an existence filled with grace, the divinization of the whole created world. This divinization that began in the Incarnate Eternal Word is a gift to every human being, and through it to the whole world. Man turns out to be a Christologically appointed mediator on the created world's way to access God. This appointment is linked, firstly, to man's ability to know the created world, which he addresses when he says "stop! - you have a harbour in me," and secondly, responsibility for all creation around him. Assuming that this responsibility should not be understood only eschatologically, the imperative to care for the good of creation should be recognised. Perhaps in the powerful words "stop!" one can hear the argument that man's ability to harmonise with the world around him is incompatible with the destructive use of this world.

The human ability to wonder appears as a theological event. It is a subtle experience of God in human life, a foretaste of a spring, some invitation to go upwards, against the current, to break through, to search, not to give way - as one could express it by referring to words from The Roman Triptych. ${ }^{34}$ This amazement, which is revealed as the imperative of going up the stream and searching for the source, is a force that allows one to go where one can make a request:

33 John Paul II, Crossing the Threshold of Hope, New York 2005.

34 John Paul II, The Roman Triptych... 


\begin{abstract}
Allow me to wet my lips
in spring water,

to feel its freshness,

reviving freshness. ${ }^{35}$
\end{abstract}

In this request there should be heard probably something more than humble call of a believing person for relief and quenching his thirst after the hardships of the way. Should not the prayerful request of theologians, who in the streams of living water (cf. Jn 7:37-39) flowing from the Heart of Jesus look for the ability to speak about the Source, be recognized in this call? Should not a communion of man with the Theologian-Christ - the Incarnate Son of God, who ceaselessly speaks of the Father in the world and arouses faith in human faith be recognized in this "wetting of lips"?

Thinking about the theological method seen in relation to the motif of amazement, which leads to reflection on man, allows us to discover the uniqueness of this man, which consists in the fact that in him there is a "meeting place" of the whole world created with the Eternal Word. It is precisely this encounter, first of man with the Eternal Word and then of the world created with the Eternal Word in man, that enables the amazed man to be a theologian in the Theologian. The uniqueness of man also lies in the fact that he is capable of a faith that leads to admiration (and even ecstasy, cf. Acts 3:10). Jerzy Szymik put it correctly when he wrote: "This kind of admiration, which is the result of faith, is not a-logical. On the contrary: because it is derived from the Logos, from the encounter with Him, so it comes from the highest logic - the logic of the Supreme. This kind of admiration is something par excellence theo-logical. And the logic ("Logosity") of faith brings about not only admiration, but also 'other effects'."

Consideration concerning the man in wonder leads to the conclusion that it is precisely in this ability to wonder that man learns something specifically proper to himself, some kind of proprium grafted in him, modelled on the proprium of Divine Persons. It is precisely this ability that allows him to discover in himself the possibility and capacity of thinking about God, who reveals Himself to man in the complexity of Divine inner life and to look at the world from the perspective of thinking about God, who not only created the world, but also in his Son and the Holy Spirit reveals that $\mathrm{He}$ is love and that He loves. Wonderment, characteristic of man, can become the foundation of theological thinking, the anticipation of knowing God and theological knowledge of the world. It can therefore be said that theological thinking demands, firstly, recognizing in man his ability to wonder,

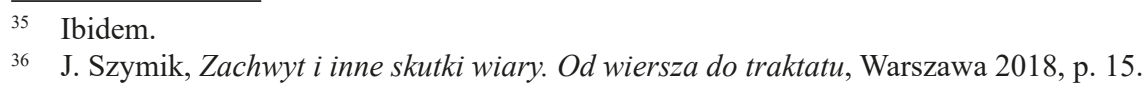


secondly, communion with the Incarnate Son of God, in whom we have access to the Father, and thirdly, an invitation coming from man to the world around him to meet the Eternal Word in him.

\section{CONCLUSION}

Wonderment seen as part of theological thinking, and thus a component of theological method, cannot be limited to experiencing emotional impulses accompanying religious practices. It therefore seems to be possible to speak of the need to observe and verify the amazement accompanying faith. The theological character of wonderment is probably confirmed not so much by the fact that questions arise from wonderment, but in a sincere search for their answers with God, who gave us the Church as an ordinary place to grow in faith and to know the Father. What opens man up to learning the deepest truth about reality - God and the created world - is, among other things, the ability to be amazed. This is what makes him open to God and to the world. This ability can be used by all creation to get closer to the source of its existence and destiny. Assuming that it is possible to speak of Eucharistic amazement, which calls for an effort to be aroused, and of amazement which can and should be revived in the Church which gathers for the celebration of the Eucharist, it is also possible to speak of amazement which allows man to come closer to thinking about God and to formulating words about Him which are based on faith and which lead the way of faith. In a sense, submissiveness to theological amazement is a task, or perhaps even a duty, of the theologian, his ability to use the theological method. The mission of a theologian is inextricably linked to cultivating within oneself the ability to be amazed with God and His works. For the arousal of faith demands amazement with God and His works which has the power to reveal itself in the lives of individuals as the certainty of faith. In the dimension of the whole Church, this same astonishment becomes a testimony to the vitality of the Gospel and the strength of missionary activity. The mission of a theologian who is faithful to the theological method is inseparably connected with cultivating in himself the ability to be amazed at God and his works, which turns out to be one of the elements leading to communion with Christ the Theologian, who reveals the Father.

\section{BIBLIOGRAPHY}

Bonaventurae S., Itinerarium mentis in Deum, Prol., 4, in: Opera omnia, vol. 5, Publisher Ad Aquas Claras (Quaracchi): Ex typographia Colegii S. Bonaventurae 1891, p. 293-316. 
Borucki T., O wzniostości w poemacie medytacyjnym na przykładzie polskiej i rosyjskiej wersji ,, Tryptyku rzymskiego” Jana Pawła II, in: Między oryginałem a przekładem, vol. 16: Wzniosłość i styl wysoki w przekładzie, ed. J. Brzozowski, M. Filipowicz-Rudek, Kraków 2008, p. 11-24.

Falkowska M., Cisza i ,milczenie” w poezji Karola Wojtyły, in: Karol Wojtyła-poeta, ed. J. Głażewski, W. Sadowski, Warszawa 2006, p. 83-95.

Il metodo teologico. Tradizione, innovazione, comunione in Cristo, ed. M. Sodi, Città del Vaticano 2008.

John Paul II, Exhortation "Pastores dabo vobis".

John Paul II, Encyclical "Ecclesia de Eucharistia”.

John Paul II, Encyclical "Evangelium vitae".

John Paul II, Encyclical "Redemptor hominis".

John Paul II, [Tryptyk rzymski], The Roman Triptich, transl. J. Peterkiewicz, Libreria Editrice Vaticana, https://www.ewtn.com/catholicism/library/roman-triptych-8369.

John Paul II, Crossing the Threshold of Hope, transl. Alfred A. Knopf, New York 2005.

Królikowski J., Nauka, mądrość i powołanie. O naturze i misji teologii, Kraków 2016.

Rusecki M., Problematyka metody w teologii, in: Tożsamość teologii, ed. A. Anderwald, T. Dola, M. Rusecki, Opole 2010, p. 43-83.

Salij J., Czy możliwa jest teologia chrześcijańska poza Kościołem?, in: J. Salij, Wiara i teologia, Poznań 2017, p. 125-145.

Salij J., Jan Pawet II jako teolog, in: J. Salij, Wiara i teologia, Poznań 2017, p. 193-227.

Salij J., Teologia czasu próby, in: J. Salij, Wiara i teologia, Poznań 2017, p. 73-91.

Smuniewski C., Wspólnota łaski. Charytologiczno-trynitarna eklezjogeneza, "Myśl Teologiczna", vol. 76, Kraków 2013.

Strzelczyk G., Własne doświadczenie wiary teologa jako integralny element metody teologicznej, in: Teologia na nowe tysiąclecie. Między barbarzyństwem a nadzieja, ed. J. Kempa, I. Bugdoł, Katowice 2005, p. 105-122.

Szczęsna E., Namyst, zdziwienie zapytywanie - o poetyce interpretacji na przykładzie „, Tryptyku rzymskiego” Jana Pawła II, w: Karol Wojtyła - poeta, ed. J. Głażewski, W. Sadowski, Warszawa 2006, p. 53-61.

Szymik J., Przekroczyć próg zdumienia. O „, Tryptyku rzymskim” Jana Pawła II, in: Karol Wojtyła - poeta, ed. J. Głażewski, W. Sadowski, Warszawa 2006, p. 62-67.

Szymik J., Zachwyt i inne skutki wiary. Od wiersza do traktatu, Warszawa 2018.

Vatican Council II, Pastoral Constitution on the Church in the Modern World. "Gaudium et spes".

Wierzbicki A.M., Pomiędzy zdziwieniem a widzeniem, in: Wokót „,Tryptyku rzymskiego” Jana Pawła II, ed. A.M. Wierzbicki, Lublin 2003, p. 89-94. 
Keywords: amazement ("stupor", "admiratio"), theological method, theologian, John Paul II

„ET STUPEBANT SUPER DOCTRINA EJUS” (MK 1:22).

O ROLI ZDUMIENIA W METODZIE TEOLOGICZNEJ

\section{Streszczenie}

Opracowanie niniejsze jest przyczynkiem do badań dotyczących metody teologicznej i ukazuje motyw zdumienia w nauczaniu i poezji Jana Pawła II jako doświadczenia zapraszającego człowieka do coraz wnikliwszego poznawania Boga i Jego dzieł. Ludzkie doświadczenie zdumienia się Bogiem zostało przedstawione jako wydarzenie teologiczne - łaska zdolności zachwytu Bogiem, przybliżenia się do Niego i mówienia o Nim. Autor artykułu dochodzi do wniosku, że z misją teologa nierozerwalnie związane jest pielęgnowanie w sobie zdolności do zdumiewania się Bogiem i Jego dziełami. Doświadczenie zdumienia jest jednym z elementów prowadzących do komunii z Chrystusem Teologiem, który objawia Ojca.

Słowa kluczowe: zdumienie ("stupor", "admiratio"), metoda teologiczna, teolog, Jan Paweł II 